\title{
Patrimônio Natural e Geoconservação: a geodiversidade do município gaúcho de Caçapava do Sul ${ }^{1}$
}

\author{
Natural Heritage and Geoconservation: the geodiversity of the city \\ Caçapava do Sul (RS), Brazil
}

\author{
Simone Marafiga Degrandi, Adriano Severo Figueiró
}

\begin{abstract}
RESUMO
O presente trabalho possui a finalidade de discutir o processo de geoconservação através da valorização da geodiversidade do município gaúcho de Caçapava do Sul para o desenvolvimento de atividades de Ecoturismo e Geoturismo, enfatizando os aspectos macroestruturais do patrimônio natural (fatores geológico-geomorfológicos). Para atingir tal objetivo, foi realizado o levantamento das principais geoformas e afloramentos rochosos com potencialidades interpretativas para o desenvolvimento do turismo no município. Através da abordagem desta temática busca-se discutir também a singularidade da paisagem em estudo e a importância da conservação de seu patrimônio natural, considerando-a como um local para a aplicação dos princípios relativos à geoconservação. A beleza cênica da configuração da paisagem de Caçapava do Sul, inserida no contexto geológico do Escudo Cristalino Sul rio-grandense e da Bacia Sedimentar do Camaquã, é marcada pela ocorrência de diversos afloramentos rochosos (principalmente arenitos paleozóicos) dispostos em forma de complexos e também de morros isolados, que compõem um patrimônio natural de ordem abiótica a ser preservado. A ocorrência de estruturas rochosas de formatos curiosos em meio à vegetação típica do Pampa gaúcho aguça o espírito aventureiro de turistas que procuram roteiros alternativos e um maior contato com a natureza. A metodologia adotada para a construção dessa análise partiu do levantamento de dados sobre a configuração da paisagem em estudo, associada às análises cartográficas e trabalhos de campo que deram suporte á pesquisa. A partir da geodiversidade encontrada no Município de Caçapava do Sul com possibilidades interpretativas para o desenvolvimento do Ecoturismo e/ou Geoturismo destacam-se: as Guaritas, a Vila Minas do Camaquã, as geoformas da Vila do Segredo, a Gruta da Varzinha, a Toca das Carretas, a Cascata do Salso, entre outras. O levantamento das geoformas presentes em um determinado território pode auxiliar, entre outros objetivos, na conservação de paisagens/sítios em situação vulnerável, a valorização do patrimônio natural e histórico-cultural dentro do contexto do turismo sustentável e a complementação da renda das comunidades que residem nestes locais de rara beleza cênica e importância científica.
\end{abstract}

PALAVRAS-CHAVE: Geoconservação; Geodiversidade; Caçapava do Sul. 


\begin{abstract}
The present study has the purpose of discussing the process of geoconservation through the valorization of the geodiversity in the Caçapava do Sul city, Rio Grande do Sul, for the development of ecotourism and geotourism activities, emphasizing macronatural aspects of the natural heritage (geological and geomorphological factors). In order to achieve this goal, we present a survey of geoforms and rocky outcrops with interpretive potential for tourism development in the city. Through this thematic approach, we seek to discuss also the singularity of the landscape under study, and the importance of conservation its natural heritage, considering it as a spot for the application of principles relating to geoconservation. The beauty scenic of the landscape configuration of Caçapava do Sul, which inserted in the geological context of the Sul-rio-grandense Shield and the Camaquã Sedimentary Basin, is characterized by the occurrence of several rocky outcrops (mainly Paleozoic sandstones) arranged in complexes, and also, of isolated hills, which compose an natural heritage of abiotic order to be preserved. The occurrence of curiously shaped rock structures amidst the typical vegetation of the Pampa gaucho instigates the adventurous spirit of tourists who look for alternative tours and a greater contact with nature. The methodology adopted for the construction of this analysis was the data collection about the configuration of the landscape under study, associated with cartographic analysis and fieldwork, which support the research. From the geodiversity found in Caçapava do Sul with interpretive possibilities for the development of ecotourism and/or Geotourism include: the Guaritas, the Vila of Minas do Camaquã, the geoforms of the Vila of the Segredo, the Gruta da Varzinha, the Toca das Carretas, the Cascata do Salso, among others. Among other objectives, the survey of geoforms present in a given territory may help, among other objectives, the conservation of landscapes / sites in a vulnerable situation, the valorization of the natural heritage, historical and cultural tourism within the context of sustainable development and complement of income for the communities residing in these places of rare scenic beauty and scientific importance.
\end{abstract}

KEYWORDS: Geoconservation; Geodiversity; Caçapava do Sul.

\title{
Introdução
}

Eu vivo o espaço como recuo no Tempo. Decifro as memórias do passado para compreender o presente que me rodeia, deixando para trás só a mais efêmera marca da minha existência: um manancial de pegadas...ou de palavras.

\section{Neto de Carvalho (A natureza das paisagens)}

O patrimônio natural ligado à diversidade dos aspectos geológicogeomorfológicos impressos na paisagem e à riqueza em recursos minerais configuram o que se entende hoje por geodiversidade (HOSE, 2010). A geodiversidade associada a outros elementos que compõem paisagens de excepcional beleza cênica tem 
atraído o interesse de turistas de natureza e despertado a atenção de pesquisadores, sensibilizados pela necessidade de conservar não apenas a biodiversidade, mas também elementos abióticos que ajudam a compor a macro-estrutura natural de paisagens singulares, como as que encontramos no município de Caçapava do Sul, localizado na Metade Sul do Estado do Rio Grande do Sul.

Ao contrário de outros países onde a interpretação geológico-geomorfológica já suscita um importante movimento no sentido da conservação da paisagem (CARVALHO; RODRIGUES; JACINTO, 2009), no Brasil ainda existe uma grande negligência quanto às leis de proteção e conservação dos aspectos abióticos notáveis da natureza, ao contrário do que ocorre com elementos da biodiversidade e da cultura. A ênfase nos processos de conservação da natureza esteve, na maioria das vezes, focada na conservação da biodiversidade, em detrimento da conservação de feições geológicas da natureza e de processos que modelaram a Terra (PEREIRA, 2010).

Pereira (2010, p.09) salienta que:

O patrimônio natural é composto por elementos bióticos, que integram a biodiversidade, e elementos abióticos, que compõem a geodiversidade. Historicamente, todas as iniciativas voltadas para a conservação deste patrimônio estiveram focadas, na sua quase totalidade, na conservação dos seus componentes bióticos, de modo que a conservação da natureza acabou por ser quase que um sinônimo exclusivo desta vertente. Todavia, a conservação dos elementos de destaque da geodiversidade, cujo conjunto representa o patrimônio geológico, é conhecida por geoconservação e foi relegada a um papel menor, ou mesmo inexistente, dentro das temáticas de conservação da natureza.

A geoconservação sintetiza os esforços para a conservação do patrimônio natural geológico-geomorfológico, englobando aspectos e processos geológicos, geomorfológicos e de solo, que se individualizam pelo seu valor científico, cultural, educativo ou de interesse cênico e recreativo. A ocorrência de formações rochosas, geoformas, depósitos sedimentares, minerais, fósseis, cavernas, quedas d' água, entre outras ocorrências geológicas que compõem a geodiversidade são recursos naturais não renováveis que constituem um importante patrimônio natural a ser conservado.

De acordo com Brilha (2005) a geoconservação, em sentido amplo, tem como objetivo a utilização e gestão sustentável de toda a geodiversidade, englobando todo o tipo de recursos geológicos.

O Serviço Geológico do Brasil - CPRM (Companhia de Pesquisa de Recursos Naturais), em livro organizado por Silva (2008) define geodiversidade como: 
(...) natureza abiótica (meio físico) constituída por uma variedade de ambientes, fenômenos e processos geológicos que dão origem às paisagens, rochas, minerais, solos, águas, fósseis e outros depósitos superficiais que propiciam o desenvolvimento da vida na Terra, tendo como valores intrínsecos a cultura, o estético, o econômico, o científico, o educativo e o turístico. (SILVA, 2008, p. 12).

A valorização dos aspectos geológico-geomorfológicos, através da geoconservação e sua procura como atrativo turístico ligado ao Turismo de Natureza, resultou na elaboração do termo "Geoturismo" para designar o turismo voltado aos monumentos naturais dos locais visitados.

Nascimento; Ruchkys e Mantesso-Neto (2007, p. 1) afirmam que:

O geoturismo compreende um novo segmento do turismo de natureza, no Brasil, que surge com a intenção de divulgar o patrimônio geológico, bem como possibilitar sua conservação. Tal atividade utiliza feições geológicas como atrativo turístico, divulgando a geodiversidade da região turística, sendo útil, portanto, para promover a associação com as atividades de ecoturismo, unindo assim, a bio e a geodiversidade.

Muitos dos parques naturais e outras categorias de áreas protegidas espalhados pelo mundo possuem um patrimônio geológico-geomorfológico singular, atraindo o incremento das atividades turísticas e a promoção da interpretação ambiental.

Como forma de aproveitamento do potencial geológico-geomorfológico envolvendo a conservação das geoformas através do desenvolvimento do turismo, o Geoturismo assim como o Ecoturismo, desempenha um papel importante no processo de interpretação da paisagem e da Educação Ambiental. A separação/vinculação dos termos Geoturismo e Ecoturismo vêm sendo discutida por alguns autores, mas ainda não há um consenso geral. Dowling; Newsome (2006), por exemplo, consideram o Geoturismo como um subsegmento do Ecoturismo. Mesmo com a individualização de conceitos distintos para estas duas vertentes ligadas ao Turismo de Natureza, tanto o Ecoturismo como o Geoturismo possuem os mesmos princípios ligados à conservação ambiental e a promoção de meios interpretativos dos elementos naturais paisagísticos.

A partir dessa perspectiva, o enfoque central do presente trabalho é discutir a importância da geoconservação através da valorização da geodiversidade do município gaúcho de Caçapava do Sul para o desenvolvimento de atividades de Ecoturismo e Geoturismo, enfatizando os aspectos macro-estruturais do patrimônio natural (fatores geológico-geomorfológicos) no município. A abordagem dessa temática devese a necessidade de uma ampla divulgação e reflexão sobre a importância da conservação dos elementos abióticos que compõem paisagens de excepcional beleza cêni- 
ca e importância geocientífica no Rio Grande do Sul e, em especial, no Município de Caçapava do Sul.

A metodologia adotada para o desenvolvimento da pesquisa envolveu o levantamento de dados sobre a configuração da paisagem da área em estudo, através de pesquisa bibliográfica, análise do mapeamento geológico, geomorfológico e de cartas topográficas nas escalas 1:250.000 e 1:50.000. Esta etapa, também foi complementada através da observação e catalogação destas formas de relevo através do software Google Earth e trabalhos de campo. Os trabalhos de campo foram realizados com intuito de identificar in loco, as geoformas e afloramentos rochosos levantados através da interpretação da imagem, formando um banco de dados referente a cada uma das estruturas. A etapa final compreendeu a interpretação dos dados obtidos e a identificação dos principais recursos turísticos ligados ao patrimônio natural de ordem abiótica de Caçapava do Sul, para o desenvolvimento do Ecoturismo e Geoturismo.

\section{Geoconservação - a conservação do patrimônio natural abiótico}

As ações relacionadas à conservação da natureza assumem uma importância crescente na sociedade atual devido aos diferentes processos de apropriação e exploração dos "recursos" naturais paisagísticos e das ameaças geradas a partir de determinadas atividades econômicas de uso do solo, sem a realização de um ordenamento territorial adequado.

A problemática recente relativa à conservação de elementos paisagísticos notáveis, relacionados à geodiversidade, segue uma tendência de expansão que engloba diversos países, com a elaboração de listas de inventário de locais com uma geologia/geomorfologia de valor destacado. Conforme destaca Azevedo (2007), experiências de geoconservação acontecem em vários países, incluindo, entre outros, a Grã -Bretanha, Portugal, Espanha, França, Itália, China, Austrália, Nova Zelândia, Malásia, Colômbia, Brasil, entre outros.

As ações de salvaguarda do patrimônio natural de ordem abiótica têm sido intensificadas, principalmente a partir da realização da Convenção para a Proteção do Patrimônio Mundial, Cultural e Natural da Organização das Nações Unidas para a Educação Ciência e Cultura (UNESCO), realizada em 1972, que reconhece internacionalmente a necessidade de conservação dos bens culturais e naturais. A convenção passa a orientar o reconhecimento de sítios culturais e naturais de excepcional interesse mundial, considerando que sua proteção seja de responsabilidade de toda a humanidade.

Em 1989, entre os sítios de importância natural, os sítios geológicos passam a ser inventariados através de uma lista elaborada sob responsabilidade da UNESCO, da União Internacional para a Conservação da Natureza (IUCN) e da União Internacional das Ciências Geológicas (IUGS). Esta lista denominada Lista Indicativa Global de Sítios Geológicos (Global Indicative Listo of Geological Sites -GILGES), foi colocada a disposição do Comitê do Patrimônio Mundial e substituída em 1996 pelo projeto 
Global Geosites (GEOSITES) da IUGS, com o objetivo de inserir a comunidade geológica em um plano global para promover a geoconservação com foco na identificação e inventário de sítios significativos para inclusão na lista do Patrimônio Mundial (MANSUR, 2010).

A partir desta iniciativa, as discussões relativas à geoconservação alcançaram grande notoriedade em nível mundial, já que grande parte dos países passou a realizar estudos e inventários com vistas à conservação de seu patrimônio geológico.

No Brasil, no âmbito do projeto GEOSITES foi criada, em 1997, a Comissão Brasileira de Sítios Geológicos e Paleobiológicos (SIGEP). A SIGEP possui a atribuição de gerenciar um banco de dados nacional de geossítios ${ }^{2}$, disponibilizando em seu site da Internet artigos científicos elaborados por especialistas que trabalharam nas áreas dos sítios cadastrados, como forma de divulgação e como forma de conservação de sítios que estejam em risco ou processo de depredação.

Conforme destacam Pereira; Brilha e Martinez (2008, p. 491-492):

A publicação desses geossítios na lista da SIGEP, ou mesmo a sua inserção na lista do Patrimônio Mundial Natural da UNESCO, não garante, por si só, a sua proteção efetiva. Desta forma, a proteção integral e a conservação dos geossítios brasileiros só podem ser asseguradas mediante a criação de unidades de proteção, baseadas nos mecanismos legais existentes no país.

A tomada de consciência sobre a necessidade de conservação do patrimônio geológico se intensifica a partir do início do século XX. O movimento crescente de reconhecimento da necessidade de conservação do patrimônio geológico contou com uma gama de eventos relacionados à geologia como, por exemplo, o I Simpósio Internacional sobre a Proteção do Patrimônio Geológico, realizado em Digne, na França em 1991, onde foi aprovada a Declaração Internacional dos Direitos à Memória da Terra, a Conferência de Malven, realizada em 1993 e os Simpósios Internacionais I e II sobre a proteção do patrimônio geológico, realizados nas cidades de Roma e Madri, respectivamente (AZEVEDO, 2007).

Entretanto, entre as iniciativas relacionadas à geoconservação que alcançaram maior repercussão destaca-se a criação dos Geoparques, iniciada em países da Europa e da China no ano 2000 (NASCIMENTO; RUCHKYS; MANTESSO-NETO, 2007).

A criação de um geoparque está vinculada a uma marca, um selo atribuído pela UNESCO a um território onde se individualizam sítios geológicos, geomorfológicos, mineralógicos, espeleológicos, paleontológicos e/ou arqueológicos, que possuam características singulares, estando em sintonia com a conservação dos elementos da geodiversidade (UNESCO).

A iniciativa de conservação da geodiversidade através da criação de um geoparque deve vir atrelada a iniciativas de educação e desenvolvimento territorial sus- 
tentável, principalmente através do turismo. Os projetos educacionais se constituem em uma iniciativa necessária para a criação de um geoparque; por isso, em praticamente todos geoparques existe um museu, vários locais de visitação (geossítios), ampla produção de folhetos, publicações, materiais didáticos, documentários, painéis interpretativos e programas educacionais relacionados às geociências (BOGGIANI, 2010).

Em princípio, um Geoparque representa um território que é suficientemente grande para gerar atividade econômica - notadamente através do turismo - promovendo a Educação Ambiental, o treinamento e desenvolvimento de pesquisa científica nas várias disciplinas das Ciências da Terra, incentivando políticas públicas de desenvolvimento sustentável (CPRM, 2011).

A alternativa de proteção deste tipo de patrimônio natural, através da criação de Geoparques, nasceu a partir do grande número de pedidos que a UNESCO recebeu do mundo inteiro, durante anos recentes, de instituições geológicas, geocientistas e organizações não-governamentais, refletindo a necessidade de uma iniciativa global para promover locais de patrimônio geológico singular (CPRM, 2011).

Em 1997, representando uma resposta direta à Convenção de Digne, a Divisão de Ciências Ecológicas e da Terra da UNESCO introduziu o conceito de uma Rede de Geoparques para apoiar os esforços nacionais e internacionais de conservação do patrimônio geológico-geomorfológico (SCHOBBENHAUS FILHO, 2010). Entretanto, a divulgação dos Geoparques alcançou grande notoriedade apenas com a criação da Rede Européia de Geoparques, em 2000, e, em seguida, com a criação da Rede Mundial de Geoparques da UNESCO em 2004 (BOGGIANI, 2010).

Schobbenhaus Filho (2010, p. 4) salienta que:

A filosofia subjacente ao conceito de Geoparques foi introduzida pela primeira vez na Convenção de Digne, França, com a "Declaração dos Direitos à Memória da Terra", assinada por especialistas de mais de 30 nações em 13 de junho de 1991, apontando que é chegada a hora de proteger o nosso patrimônio natural registrado nas rochas e paisagens, ou seja, o nosso patrimônio geológico. O conceito de Geoparques representaria uma resposta direta como um meio de proteger e promover o patrimônio geológico e o desenvolvimento sustentável local, por meio de uma rede global de territórios possuindo uma geologia de valor destacado.

No Brasil, o Projeto Geoparques é coordenado pela CPRM, que objetiva identificar, classificar, descrever, catalogar, georreferenciar e divulgar locais de interesse e com potencial para a criação de geoparques no país, bem como definir diretrizes para seu desenvolvimento. Estas atividades devem ser desenvolvidas em conjunto com as universidades, órgãos ou entidades federais e estaduais, que tenham interesses comuns, e em consonância com os interesses das comunidades locais. Desde 2006 a 
CPRM vem estudando o patrimônio geológico brasileiro com potencial para a criação de geoparques e atualmente conta com vários projetos em áreas potenciais, que se encontram em diferentes fases de execução.

A inclusão na lista da SIGEP, não significa uma indicação ao Projeto Geoparques da UNESCO; entretanto, atua em sintonia com os princípios da geoconservação, tendo como foco principal o levantamento dos mais importantes sítios geológicos e paleontológicos do Brasil (DEGRANDI, 2011).

O conceito de Geoparque, em larga escala de implantação em todo mundo, tem possibilitado a divulgação do papel da geoconservação, contribuindo para a incorporação da conservação do patrimônio geológico na legislação de diversos países (PEREIRA; BRILHA; MARTINEZ, 2008) e permitindo a ampliação do conhecimento geológico, levado ao público em geral.

A conservação de sítios geológicos somente pode ser alcançada através da educação em geociências (SCHOBENHAUS FILHO; SILVA, 2010; SLOMKA; MAYER, 2010) e da promoção da geoconservação através da utilização de locais-chave para a promoção da interpretação e da Educação Ambiental. Nesse sentido, a divulgação do trinômio geodiversidade, geoconservação e geoturismo pode atuar positivamente na conservação do patrimônio natural, seja ele de origem biótica ou abiótica, permitindo reconhecer, estudar e interpretar a evolução da história geológica da Terra e os processos que têm contribuído para o modelado da paisagem.

Entre os principais objetivos da geoconservação está a conservação e a manutenção da geodiversidade, a minimização dos impactos adversos dos locais importantes em termos de geoconservação, a oportunidade dos visitantes de áreas protegidas interpretarem a geodiversidade e contribuir para a manutenção dos processos ecológicos dependentes da geodiversidade (SHARPLES, 2002).

Para Azevedo (2007, p. 12):

Além de seu valor como base e suporte para os aspectos biológicos, culturais e históricos, a geoconservação tem também um valor em si mesma, como forma de proteção das fontes de informação sobre a história geológica da Terra. A importância da geoconservação é ainda maior se considerarmos que as estruturas geológicas são geradas por processos cuja escala temporal é, de um modo geral, de milhões ou bilhões de anos.

A geoconservação atua no sentido de aprofundar o conhecimento e modificar a maneira de pensar e sensibilizar o visitante de cavernas, cachoeiras, sítios paleontológicos, entre outros atrativos geoturísticos, quanto à necessidade de conservarmos nosso patrimônio natural de ordem abiótica. Neste sentido, a criação de Geoparques representa uma ferramenta valiosa para a conservação da geodiversidade, contribuindo com a divulgação das Geociências para sociedade através de diferentes projetos educacionais, que devem ser priorizados entre as atividades previstas em um Geoparque. Além disso, os Geoparques despontam como uma nova proposta de uso sus- 
tentável do território e de suas particularidades enquanto atrativos turísticos, valorizando identidades e resgatando valores histórico-culturais.

\section{A Configuração da Paisagem de Caçapava do Sul}

O Município de Caçapava do Sul, localizado na Metade Sul do Estado do Rio Grande do Sul (RS) (Figura 1), está inserido no contexto geológico do Escudo Cristalino Sul Rio-grandense e da Bacia Sedimentar do Camaquã. Geologicamente essa região apresenta a litologia mais antiga do RS. Do ponto de vista geomorfológico o Escudo Cristalino Sul rio-grandense apresenta-se como uma área de forte rebaixamento e predominância de meteorização física e química (VIEIRA, 1984). As estruturas mais resistentes à alteração constituem os principais desníveis, dando ao relevo características de serras, o que acabou se consagrando como "Serras do Sudeste", com altitudes que variam entre $250 \mathrm{~m}$ a $450 \mathrm{~m}$. O relevo apresenta uma grande heterogeneidade geomorfológica com o predomínio de paisagens com declividades acentuadas.

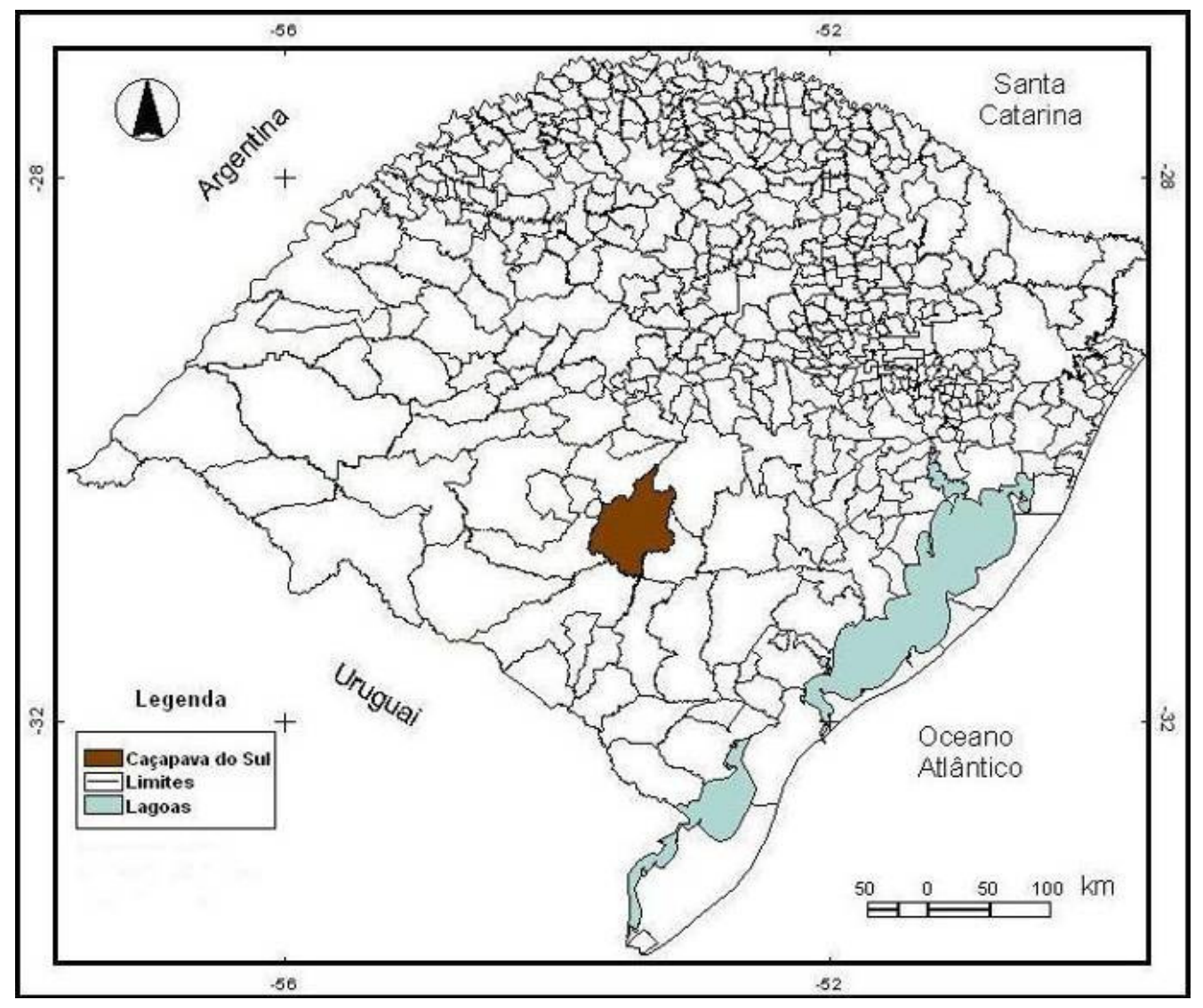

Figura 1: Mapa de localização do Município de Caçapava do Sul no Estado do RS. Org. - Simone Marafiga Degrandi, 2011.

Figure 1: Location map of the City Caçapava do Sul in the State of RS, Brazil. By Simone Marafiga Degrandi, 2011. 
A Bacia do Camaquã registra no RS os episódios vulcano-sedimentares do estágio de transição da Plataforma Sul-americana e está relacionada aos processos tectono-magmáticos tardios do Cinturão Dom Feliciano (evento Brasiliano no Sul do Brasil) (PAIM; LOPES, 2000). Esta bacia sedimentar está assentada sobre terrenos ígneos e metamórficos do Escudo Sul rio-grandense, apresentando um contexto de preenchimento bastante complexo, para uma área relativamente pequena. As formações rochosas fazem parte da Província da Mantiqueira, com rochas do Pré-Cambriano, com coberturas Sedimentares Cenozóicas e Gondwânicas (SEPLAG, 2008).

O Município de Caçapava do Sul apresenta, em virtude dessa complexidade do embasamento geológico, feições geomorfológicas que lhe conferem um caráter singular na configuração da paisagem regional, formada pela diversidade de vales e serras, afloramentos rochosos e vegetação típica do Bioma Pampa.

A complexidade da macro-estrutura natural descrita, revela uma combinação particular de elementos naturais bióticos e abióticos, que acabaram conferindo singularidade ao conjunto de municípios localizados sobre a área do Escudo Cristalino.

A combinação destes elementos paisagísticos naturais compõe um importante patrimônio natural do Rio Grande do Sul, com forte poder de atração turística e possibilidades de interpretação ambiental. Os solos rasos e pedregosos são geralmente litólicos, de pouca profundidade, apresentando afloramentos de rocha em áreas de relevo ondulado a fortemente ondulado, sendo vulneráveis à erosão e conferindo grandes restrições ao uso agrícola. Porém, este condicionamento natural permite o surgimento de diversas espécies endêmicas, principalmente de cactáceas e de répteis que vivem junto aos afloramentos rochosos, característicos na paisagem local (SEPLAG, 2008).

A grande extensão de afloramentos rochosos e a presença de elevado número de espécies endêmicas junto a estes afloramentos, tanto em Caçapava do Sul quanto nos demais municípios do Escudo Cristalino Sul-riograndense, faz com que esta seja considerada uma das áreas de extrema prioridade para a conservação pelo Ministério do Meio Ambiente (MMA, 2000).

A Secretaria Estadual de Planejamento e Gestão do RS - SEPLAG (2005b, p. 53) menciona que nesta porção do Estado:

(...) o conjunto florístico é peculiar e apresenta influências pampeana, chaquenha e andina, com muitos endemismos, principalmente com relação às Cactáceas e Bromeliáceas rupícolas. As formações vegetais apresentam escleromorfismo acentuado em decorrência de condições climáticas (inverno com temperaturas muito baixas e verão seco) e edáficas.

Conforme destaca a SEPLAG (2008, p. 80) "a região como um todo constitui um complexo mosaico de distintas formações que são redutos para ocorrência de fau- 
na e flora ameaçadas ou raras, de grande importância para a biodiversidade". O mosaico da vegetação campestre Sul rio-grandense oferece condições para a presença de uma fauna diversa, sendo encontrados cervídeos, felinos silvestres, avifauna rica, entre outras espécies. Algumas se encontram seriamente ameaçadas de extinção, constando na Lista de Referência da Fauna Ameaçada de Extinção no Rio Grande do Sul. O desconhecimento sobre o meio biótico da área ainda é grande, em que pese ser uma das áreas mais ricas em biodiversidade do Rio Grande do Sul (SEPLAG, 2008).

No que compete ao uso e ocupação do solo, as atividades agrícolas restringem -se a pequenas lavouras de subsistência e a principal atividade econômica está representada pela pecuária extensiva, realizada na sua maioria, em pequenas e médias propriedades. A mineração também ocupa um lugar de destaque na economia Caçapavana, visto que este Município é responsável pela produção de cerca de $85 \%$ do calcário no RS. Além do calcário, explorado por sete empresas, a mineração do cobre no distrito mineiro Minas do Camaquã foi realizada desde o início do século XX até o ano de 1996, quando as reservas economicamente viáveis se esgotaram.

O desenvolvimento socioeconômico regional vem tendendo a adotar modelos de uso do espaço incompatíveis com a conservação da biodiversidade e das particularidades geológicas e pedológicas frágeis do contexto regional, devido à introdução da silvicultura com espécies exóticas como o Pinus, a Acácia Negra e Eucalipto, em áreas típicas do Bioma Pampa.

As características, geológicas, geomorfológicas, litológicas, paleontológicas, entre outras, de Caçapava do Sul, além de sua singularidade, permitem a interpretação da história evolutiva do Escudo Sul rio-grandense, a partir de uma série de eventos ao longo do tempo geológico. O próprio sítio sobre o qual se assenta a área urbana do Município, denominado "Granito Caçapava", se constitui em um sítio de importância geológica. Em estudos recentes, alguns pesquisadores com o apoio da SIGEP vêm propondo o reconhecimento de geossítios em Caçapava do Sul, a exemplo do sítio das Guaritas, de caráter sedimentar e especial relevância geomorfológica, além do geossítio Minas do Camaquã, relacionado à história da mineração no Brasil.

A seguir, descrevemos os principais pontos de efetivo interesse turístico ligados à geodiversidade de Caçapava do Sul.

\section{Minas do Camaquã e Guaritas}

No distrito mineiro Minas do Camaquã estão localizadas formações geológicas muito interessantes dentro do contexto evolutivo da Bacia do Camaquã (PAIM; LOPES, 2000), bem como do ponto de vista turístico. As principais formações a serem destacadas nesta localidade são as Guaritas (várias geoformas) e as geoformas localizadas no sítio urbano da Vila Minas do Camaquã. Estas formações rochosas constituem-se em excelentes pontos e mirantes naturais para a observação da paisagem local. 
As Guaritas (Figura 2) representam uma beleza paisagística única, consideradas pela Secretaria Estadual de Turismo (SETUR/RS) como a $7^{\text {a }}$ maravilha natural do Estado. Estas formações caracterizam-se pelo relevo ruiniforme e pela presença de curiosos conjuntos de torres, expondo afloramentos de rochas sedimentares ordovicianas de origem eólica e fluvial, que fazem parte da denominada Serra do Sudeste.
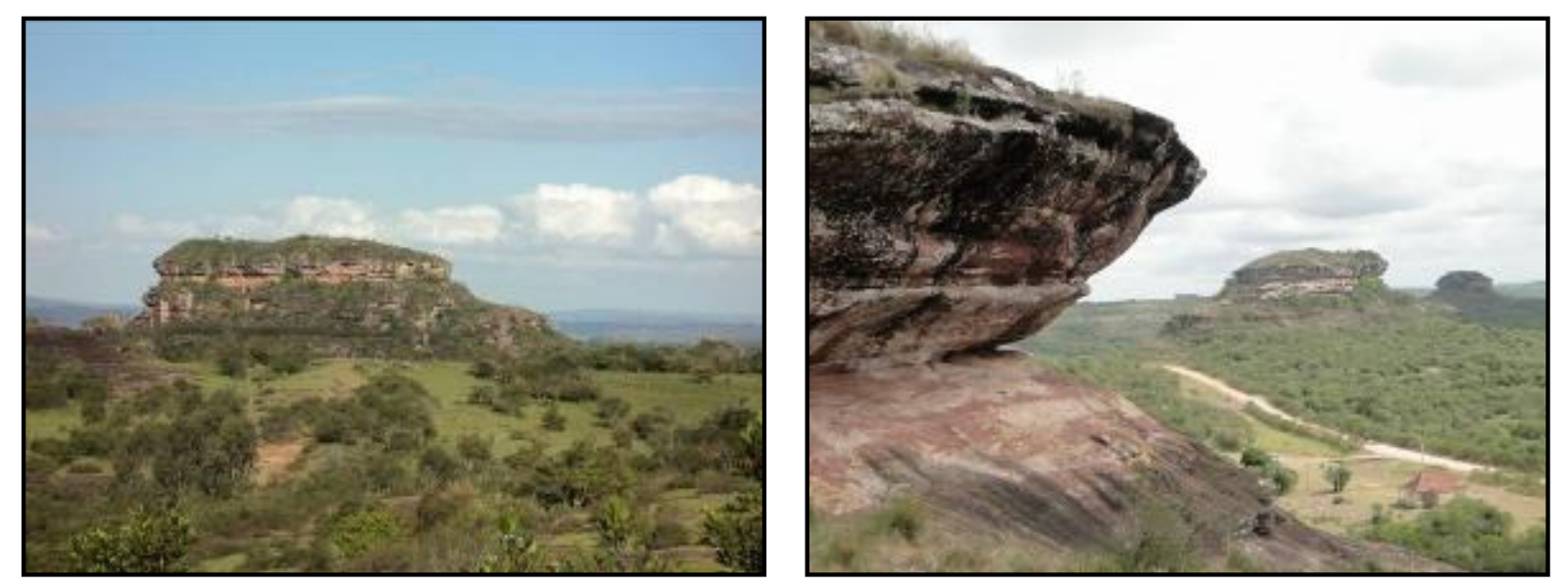

Figura 2: Relevo ruiniforme na região das Guaritas, Caçapava do Sul. Fotos: Simone Marafiga Degrandi, 2010.

Figure 2: Relief ruinform iof Guaritas $\mathrm{n}$ the region of Caçapava do Sul. Photos: Simone Marafiga Degrandi, 2010.

As formas do relevo, caracterizadas pela presença de vários morros isolados, gerados a partir de processos erosivos formando grutas e abrigos, utilizados como guaritas e casamatas, serviram como lugar de guarda e emboscada durante a Revolução Farroupilha, daí advindo o nome "Pedras das Guaritas" (PAIM; FALLGATTER; SILVEIRA, 2010).

As guaritas, conforme destacam Paim; Fallgatter e Silveira (2010, p. 2):

(...) compreendem belas feições geomorfológicas na forma de morros escarpados que, em conjunto, definem uma aparência ruiniforme. Essa paisagem deriva da erosão diferencial ao longo de sistemas de fraturas, aproximadamente ortogonais entre si, que recortam arenitos e conglomerados horizontalizados e avermelhados. A alteração química e biológica, intensificada ao longo das zonas mais permeáveis definidas pelas fraturas, facilitou e orientou a erosão dominantemente pluvial e, assim, o desenvolvimento do aspecto ruiniforme.

As Minas do Camaquã (Figura 3 a e b) são um importante sítio geológicometalogenético que representa um marco da história da mineração de cobre $(\mathrm{Cu})$ no 
Brasil (PAIN, 2009). Além do cobre ocorrem mineralizações disseminadas e filoneadas de $\mathrm{Pb}, \mathrm{Zn}, \mathrm{Au}$ e Ag. A descoberta do minério de cobre ocorreu em 1865 por mineiros ingleses que garimpavam ouro em Lavras do Sul, RS. A partir da descoberta, estabeleceram-se vários ciclos de exploração do minério de cobre e subprodutos, até que em maio de 1996 ocorreu o esgotamento total das reservas economicamente viáveis conhecidas.

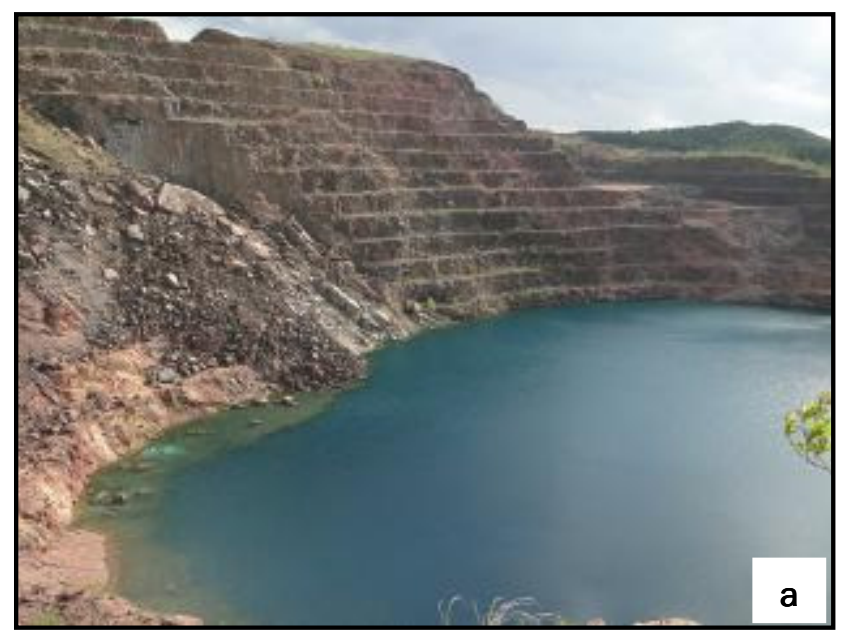

Figura 3: Minas do Camaquã, Caçapava do Sul: a) Mina Uruguai a céu aberto e b) vista do alto da Pedra da Cruz para a Vila Minas do Camaquã. Foto: Simone Marafiga Degrandi, 2010.

Figure 3 - Mines of Camaquã, Caçapava do Sul: a) open pit Uruguay mine b) view from the top of Pedra da Cruz to the Vila Minas Minas do Camaquã. Photo: Simone Marafiga Degrandi, 2010.

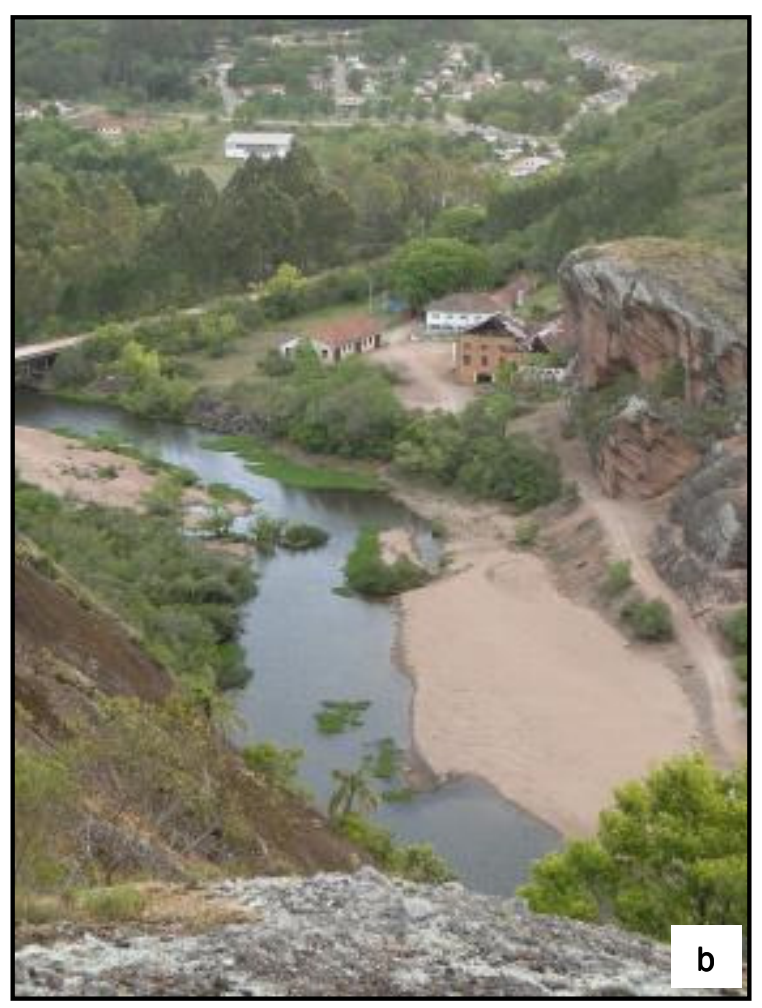

Na Vila Minas do Camaquã se destacam as geoformas Pedra da Cruz e Pedra do Engenho (Figura $4 \mathrm{a}$ e $\mathrm{b}$ respectivamente), localizadas às margens da antiga represa do Arroio João Dias. Estas estruturas que oferecem boas condições de acessibilidade para a realização de trilhas e de observação da paisagem local se constituem em exemplos didáticos da evolução paleogeográfica das sucessões sedimentares expostas, formadas principalmente por arenitos conglomeráticos e conglomerados, alternando-se em camadas pouco espessas de arenitos finos a médios.

A Pedra da Cruz possui camadas inclinadas e representa um exemplo da discordância angular que delineia o contato entre as formações rochosas sedimentares intercaladas como arenitos, conglomerados e arenitos conglomeráticos, formados a partir de depósitos fluviais, deltaicos e marinho raso, desenvolvidos na área (PAIM; LOPES, 2000).

Além disso, junto a três outros grandes afloramentos rochosos, a Pedra da 
Cruz constitui um importante testemunho da "Janela Bom Jardim" (Figura 4 c) que representa um sistema de basculamento em arenito, que fez com que a coluna estratigráfica se inclinasse nesta área, expondo quatro pontas de um sistema de dobras que foi erodido. Conforme a descrição de Ronchi, et al (2000) o Morro da Cruz constitui o primeiro de uma curiosa sequência de quatro elevações em forma de capuz, quando vistos em perfil.
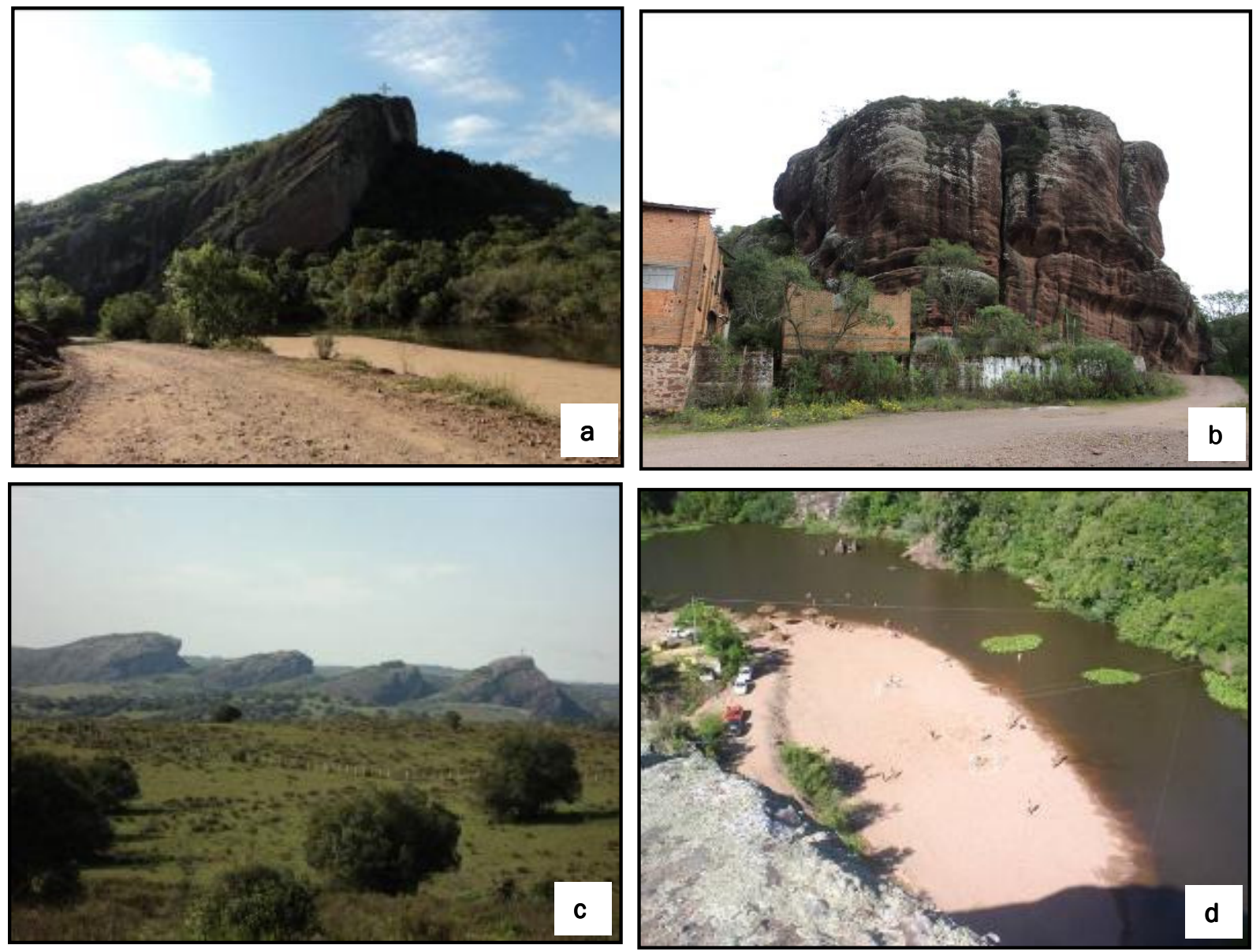

Figura 4: a) Pedra da Cruz vista da base; b) Vista frontal da Pedra do Engenho; c) Vista do sistema de basculamento (Janela Bom Jardim) e d) Área de camping e lazer localizada ao sopé da Pedra da Cruz, às margens do Arroio João Dias (fonte: <http://www.panoramio.com/photo/6804306>. Foto: a, b e c, Simone Marafiga Degrandi, 2010.

Figure 4: a) Pedra da Cruz view of the base, b) Frontal view of the Pedra do Engenho c) View of the dumping system (Janela Bom Jardim) and d) for camping and recreation area located at the foot of $\mathrm{Pe}-$ dra da Cruz, on the margins of Arroio João Dias (source: <http://www.panoramio.com/photo/6804306>.

Photos: a, b, by Simone Marafiga Degrandi, 2010.

A Pedra do Engenho recebeu esta denominação por estar localizada ao lado de uma das antigas construções utilizadas para o beneficiamento do cobre, possuindo as mesmas características sedimentares da Pedra da Cruz. A atividade econômica 
mais significativa desenvolvida na área das Guaritas e Minas do Camaquã é a criação de gado de corte, a ovinocultura e, em menor escala, a criação de caprinos. Entretanto, a exuberante paisagem tem demandado um incremento das atividades turísticas, já que a Vila mineira conta com infraestrutura completa e um importante patrimônio histórico-cultural e arquitetônico associado à história da mineração do cobre em Caçapava do Sul.

Após o esgotamento das reservas minerais economicamente viáveis em 1996, a vila e seus moradores permaneceram à espera de uma solução para a utilização das infraestruturas montadas, nutrindo ainda a esperança de que novas reservas viáveis fossem descobertas. Ainda permanecem na vila pesquisadores que desenvolvem estudos sobre o potencial de mineração nas minas desativadas, porém, até o momento, nenhuma nova jazida com boa viabilidade comercial foi descoberta.

Conforme salientam Ronchi; Lobato (2000, p. 16) "(...) atualmente o impacto negativo mais importante não é proveniente da atividade mineradora, mas, ao contrário, é social e decorrente do encerramento da atividade". As atividades de mineração são, de fato, extremamente impactantes do ponto de vista ambiental. Porém, dentro de um contexto voltado ao desenvolvimento sustentável, uma boa alternativa seria a recuperação ambiental e/ou redestinação das áreas degradadas pela mineração e o aproveitamento do potencial natural para o desenvolvimento do turismo e de atividades educacionais e de pesquisa.

O conjunto ímpar de características geológicas somadas à história da produção mineral pode tornar-se um importante circuito de Ecoturismo e Geoturismo, além de contribuir para resguardar a memória acerca das Minas do Camaquã. Neste sentido, Paim (2009) destaca que a beleza natural da região que contorna as Minas do Camaquã, incluindo as Guaritas, onde a erosão diferencial de arenitos e conglomerados acabou por gerar feições geomorfológicas exóticas de grande beleza cênica, somada a existência de uma boa infraestrutura na vila mineira, pode propiciar usos alternativos para a área em questão.

Alguns prédios utilizados durante o período em que as Minas estavam em atividade foram adaptados e hoje servem como hotel e restaurante, porém, existem muitos outros espaços físicos subaproveitados que necessitam de revitalização e reparos, que poderiam ser redestinados para as mais diversas atividades ligadas ao desenvolvimento do turismo.

\section{Geoformas da Vila do Segredo}

Na porção sudoeste do município se destacam diversas geoformas localizadas na Vila do Segredo, inserida na Formação Santa Bárbara, de origem continental, composta por arenitos, conglomerados e siltitos avermelhados, onde ocorrem associações de fácies de leques aluviais, frente deltaica aluvial, lacustre e de canais fluviais entrelaçados, arenosos e cascalhentos (BORBA, 2001; BORBA, MISUSAKI, 2003). A Formação Santa Bárbara nessa área é formada por conglomerados basais bastante gros- 
seiros, que com o aplainamento gradativo das áreas-fonte, tornaram-se mais finos (IBGE, 1986). Como resultado de um aumento gradativo das condições de transporte esta sequência torna-se mais conglomerática, até passar definitivamente a espessos pacotes de conglomerados e arenitos conglomeráticos.

As estruturas exibidas pela Formação Santa Bárbara estão intimamente relacionadas à tectônica rígida sim e pós-deposicional decorrentes dos falhamentos que ocorreram no fim do Pré-Cambriano e início do Paleozóico (BORBA, 2006). Como resultado, as camadas então depositadas sofreram basculamento de blocos, com consequente inclinação dos estratos e formação de aparentes dobras sinclinais (IBGE, 1986).

A Vila do Segredo está localizada em uma paisagem formada por serras e vales, onde estão localizadas diversas geoformas (Figura 5) com possibilidades interpretativas famosas pelas feições curiosas e variadas, que acabaram recebendo denominações dadas por montanhistas e/ou escaladores que escalam diversas vias nesta localidade.
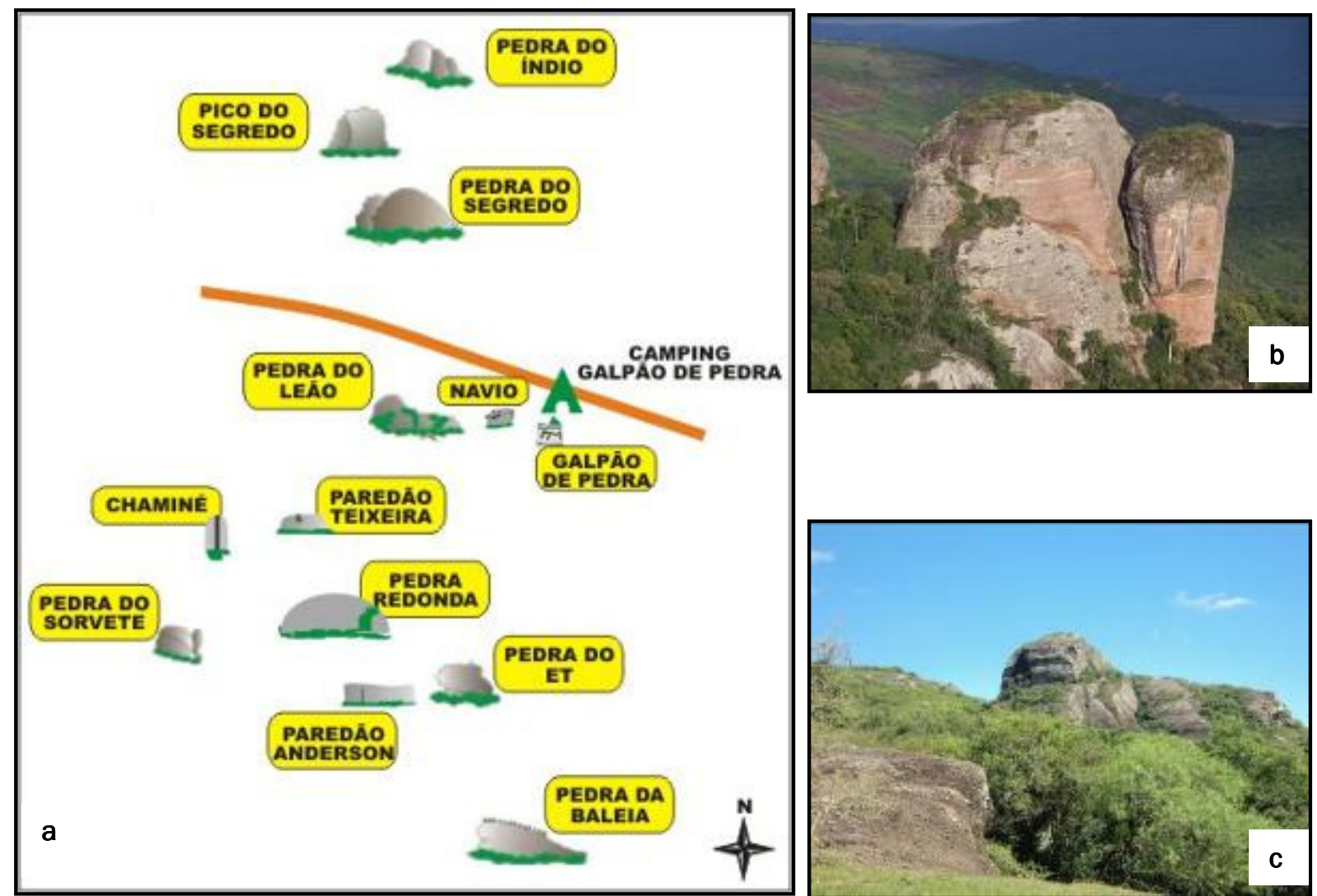

Figura 5: a) Croqui esquemático do Camping Galpão de Pedra e entorno (Fonte: <http:// www.galpaodepedra.cacapava.net>); b) Pedra do Sorvete e c) Pedra do Leão, localizadas no camping Galpão de Pedra. Foto: b) e c) Simone Marafiga Degrandi, 2011.

Figure 5: a) Schematic Sketch Camping Galpão de Pedra and the surrounding area (Source - <http:// www.galpaodepedra.cacapava.net>); b) Pedra do Sorvete; c) Pedra do Leão, located in Galpãp de Pedra camping. Photos: $b$ and c by Simone Marafiga Degrandi, 2011. 
As serras são denominadas de Serra do Segredo e Serra dos Lanceiros e os vales que as sucedem e que cercam estas serras recebem denominações homônimas. No Vale do Segredo, nas proximidades do Arroio dos Lanceiros, podemos encontrar as geoformas Pedra do Segredo (Figura 6), o Pico do Segredo e a Pedra do Índio. A geoforma mais conhecida é a Pedra do Segredo, localizada no Parque Municipal da Pedra do Segredo.
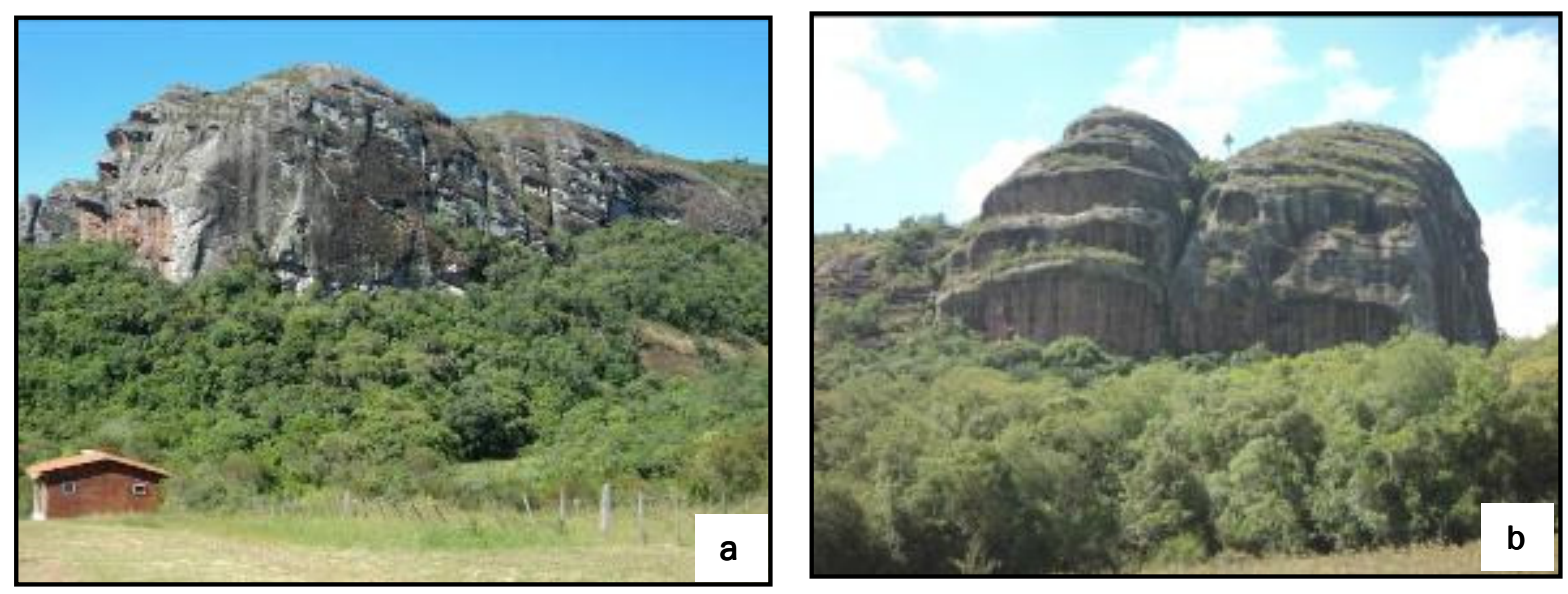

Figura 6: Pedra do Segredo, a) vista lateral e b) vista frontal. Foto: Simone Marafiga Degrandi, 2010.

Figure 6: Pedra do Segredo, a) side view b) front view. Photo: Simone Marafiga Degrandi, 2010.

A Pedra do Segredo apresenta em sua face Sul três cavernas. A primeira caverna, situada em sua base é denominada Toca Escura. Esta caverna, situada no topo de um depósito de tálus, possui mais de $100 \mathrm{~m}$ de galerias (AULER; STÁVALE, 2005) que dão acesso à face voltada para o Norte da geoforma. A cerca de $50 \mathrm{~m}$ de altura da base, no meio da Pedra, encontra-se a Gruta Salão das Estalactites, com $22 \mathrm{~m}$ de largura. A última caverna teve sua passagem aberta artificialmente, com o objetivo de facilitar a entrada na caverna que é denominada Gruta da Pedra do Segredo e possui $17 \mathrm{~m}$. As três cavernas da Pedra do Segredo estão incluídas na classificação de cavernas mapeadas pela Sociedade Brasileira de Espeleologia (SBE), compondo - Cadastro Nacional de Cavernas do Brasil (CNC). Segundo o catálogo das maiores cavernas do RS cadastradas na SBE as cavernas da Pedra do Segredo ocupam, respectivamente a $4^{\mathrm{a}}$, $13^{\mathrm{a}}$ e $19^{\mathrm{a}}$ posição no ranking.

\section{Toca das Carretas}

A Toca das Carretas (Figura 7) é na verdade uma caverna "esculpida" em rochas conglomeráticas e areníticas da Formação Guaritas (IBGE, 1986). As diversas aberturas em forma de "tocas" na porção exterior da cavidade principal originaram o nome dado ao local. Esta caverna está assentada sobre a Formação Guaritas, caracterizada pela presença de conglomerados, arenitos quartzosos, arenitos conglomeráti- 
cos, com seixos dispostos ao longo das lâminas dos estratos, com coloração vermeIha a rósea (IBGE, 1986).

A Toca das Carretas, localizada em uma propriedade particular, serviu como abrigo natural aos índios Charruas que viviam pelas redondezas de Caçapava do Sul e também como esconderijo e abrigo aos farrapos durante a Revolução Farroupilha.
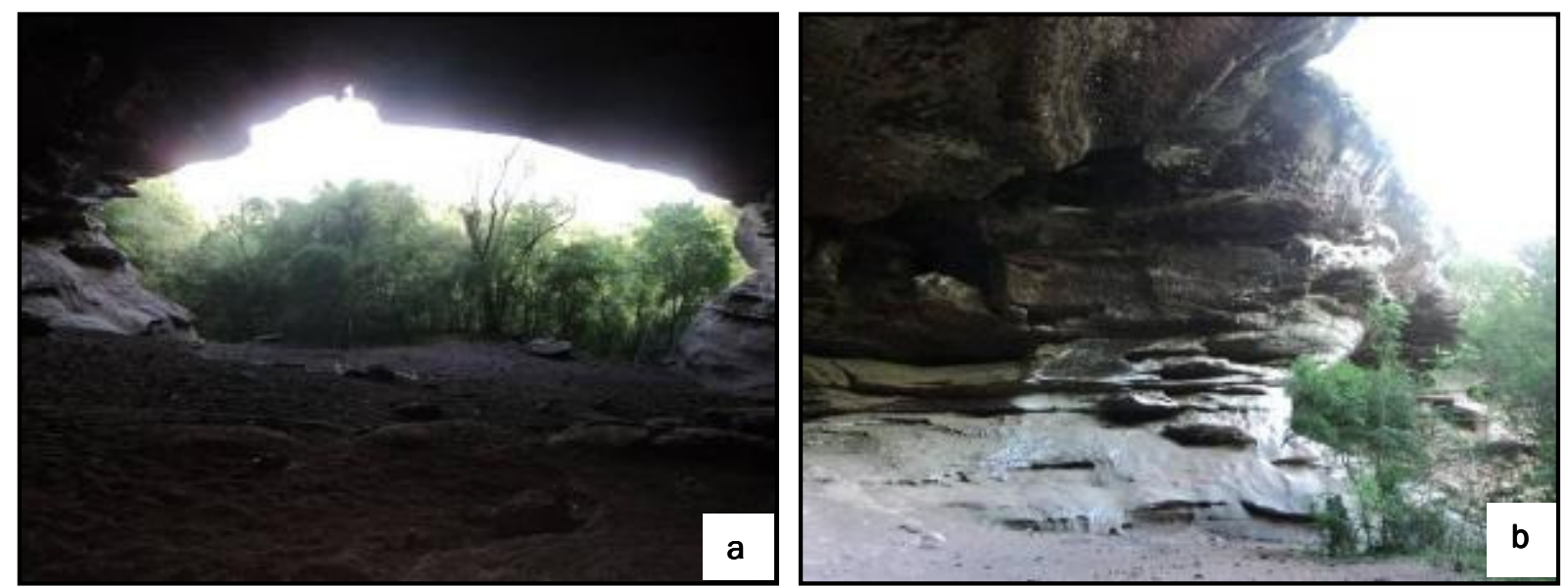

Figura 7: a) Vista interior da Toca das Carretas e b) Vista da parte exterior da Toca das Carretas, destacando as "tocas esculpidas" na rocha. Foto: Simone Marafiga Degrandi, 2011.

Figure 7: a) Inside view of the Toca das Carretas and b) outside iew of the of the Toca das Carretas, highlighting the "holes carved" into the rock. Photo: Simone Marafiga Degrandi, 2011.

A Toca das Carretas também está incluída na classificação de cavernas mapeadas pela SBE compondo o Cadastro Nacional de Cavernas do Brasil (CNC). No RS esta caverna ocupa a $9 \underline{\text { a }}$ posição no ranking, com $60 \mathrm{~m}$ de abertura. A importância histórica da caverna e as impressionantes tocas em sua face exterior constituem uma das mais interessantes geoformas de Caçapava do Sul, com especial potencial de atratividade visto a relativa facilidade de acesso, já que se localiza as margens da BR392.

\section{Gruta da Varzinha}

A Gruta da Varzinha (Figura 8) inserida na Formação Guaritas (Aloformação Varzinha) (IBGE, 1986), igualmente caracterizada por arenitos, conglomerados e siltitos, é formada por um extenso abrigo natural, com cerca de 300 metros de comprimento, que apresenta três cavidades principais.

As estalactites e estalagmites que dão a denominação de "gruta" a esta geoforma foram formadas a partir da hipercolação de água bicarbonatada em fraturas das rochas sedimentares. Apesar de ocorrer em uma área de rochas sedimentares, a Gruta da Varzinha possui uma abundante formação de espeleotemas, resultado da sedi- 
mentação e cristalização de minerais dissolvidos na água, possivelmente de calcita, incluindo formas raras como helictites.
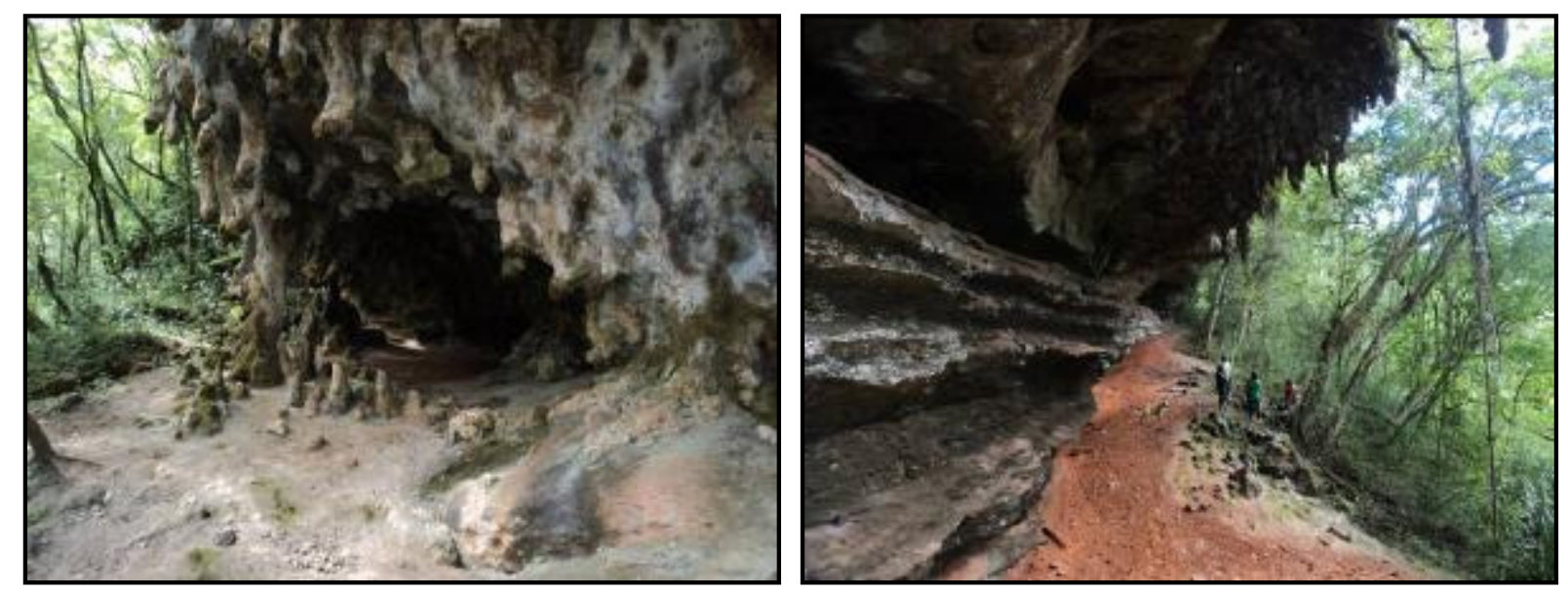

Figura 8: Gruta da Varzinha, Caçapava do Sul. Fotos: Simone Marafiga Degrandi, 2011.

Figure 8: Gruta da Varzinha, Caçapava do Sul. Photos: Simone Marafiga Degrandi, 2011.

Conforme destacam Auler; Stávale (2005), provavelmente o arenito nesta região apresenta alta concentração de carbonatos. Em alguns pontos da gruta observa-se a formação de espeleotemas de cor verde indicando a ocorrência de malaquita. Mas em geral, os espeleotemas são tipicamente brancos, derivando da calcita ou da dolomita.

A Gruta da Varzinha está incluída na classificação de cavernas mapeadas pela Associação Brasileira de Espeleologia, compondo o Cadastro Nacional de Cavernas do Brasil (CNC). Como é composta por três principais cavidades, foram atribuídos a estas cavidades os nomes de Gruta da Varzinha I, Gruta da Varzinha II e Gruta da Varzinha III. A maior cavidade é a Gruta da Varzinha III com 137 metros, constituindo a terceira maior caverna mapeada do Rio Grande do Sul. A Gruta da Varzinha I com 79 metros e a Gruta da Varzinha II com 17 metros ocupam, respectivamente, a sexta e a vigésima posição no ranking das maiores cavernas do Rio Grande do Sul.

\section{Cascata do Salso}

A Cascata do Salso (Figura 9) é formada por uma queda d' água de mais de $20 \mathrm{~m}$ de altura, situada em uma Área de Preservação Permanente. A denominação dada é em virtude do Arroio do Salso, afluente do Arroio Bom Jardim, que abriga a antiga Barragem do Salso, que fornecia energia elétrica para o município. Geologicamente a Cascata do Salso está inserida na Suíte Intrusiva Caçapava do Sul (IBGE, 1986) conhecida como Granito Caçapava, composta por rochas graníticas de coloração cinza-claro a castanho-avermelhada. 


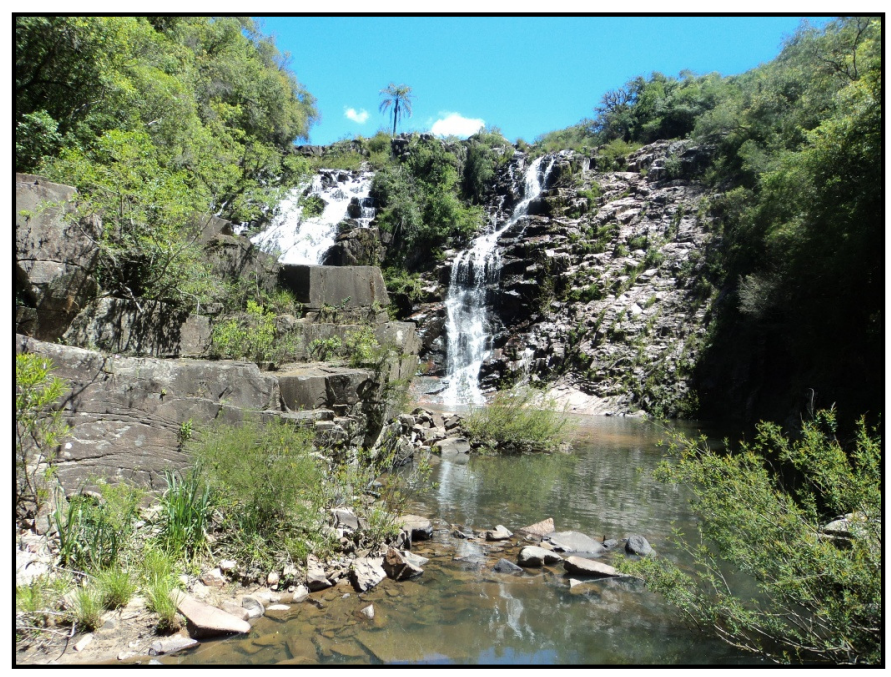

Figura 9: Cascata do Salso. Foto: Simone Marafiga Degrandi, 2010.

Figure 9: Cascata do Salso. Photo: Simone Marafiga Degrandi, 2010.

Em Caçapava do Sul, praticamente a totalidade dos pontos naturais de interesse para o Ecoturismo e Geoturismo estão localizados em pequenas propriedades privadas que realizam a agropecuária como principal atividade econômica. A única exceção é o Parque Municipal da Pedra do Segredo, que se constitui em uma das únicas áreas de proteção, estabelecidas por lei, para o conjunto de afloramentos rochosos encontrados no Escudo sul-riograndense. Neste Parque, as visitas podem ser agendadas com guias que realizam trilhas e desenvolvem projetos educacionais em parceria com escolas do município.

A realização de trilhas em meio aos afloramentos rochosos é a principal atividade ligada ao ecoturismo e geoturismo, seguida das atividades de escalada, rapel e montanhismo, praticadas por turistas de todo o RS que procuram os paredões de rocha conglomerática e a beleza cênica da paisagem como forma de contato com a natureza.

O município ainda não possui roteiros oficiais e nem empresas especializadas ou guias para a realização de visitas aos pontos turísticos. A visitação é realizada por intermédio dos proprietários que residem próximo aos afloramentos rochosos.

Caçapava do Sul poderá futuramente se destacar no cenário ecoturístico e geoturístico gaúcho por apresentar um singular patrimônio geológico-geomorfológico, acrescido de belezas naturais bióticas e abióticas e um diversificado patrimônio cultural. Em meio à vegetação típica do Bioma Pampa gaúcho, as geoformas esculpidas pela ação das intempéries ao longo de milhares de anos, ajudam a compor uma das paisagens mais belas e intrigantes do Rio Grande do Sul. 


\section{Considerações Finais}

Durante as últimas duas décadas, se consolidaram internacionalmente as iniciativas para proteção da geodiversidade, contribuindo para a valorização e divulgação do patrimônio natural de ordem abiótica. A paisagem do Município de Caçapava do Sul apresenta uma grande geodiversidade, que pode ser utilizada como atração ecoturística e geoturística e para o próprio conhecimento e valorização de seu patrimônio natural pela comunidade local e pelos turistas. Apesar da singularidade das paisagens descritas, não existem políticas públicas de proteção atreladas a geoconservação em Caçapava do Sul. A beleza cênica dos diversos afloramentos rochosos possui um potencial interpretativo especial, capaz de desencadear a conservação da paisagem a partir da aliança entre o turismo de baixo impacto e o processo de interpretação promovido pela Educação Ambiental.

A configuração da paisagem, marcada pela ocorrência de afloramentos rochosos singulares e a diversidade natural associada ao Bioma Pampa gaúcho merecem atenção especial por parte do poder público e da comunidade científica, por apresentarem características naturais importantes a serem conservadas.

Dessa forma, a realização de um inventário das geoformas presentes em um determinado território pode representar, entre outros objetivos, a proteção de paisagens/ sítios em situação vulnerável, a valorização do patrimônio natural e histórico-cultural dentro do contexto do turismo sustentável e a complementação da renda das comunidades que residem nestes locais de rara beleza cênica e importância científica.

O Município de Caçapava do Sul poderá, futuramente, ser considerado um bom exemplo para a aplicação dos princípios da geoconservação e do desenvolvimento do Ecoturismo e Geoturismo, como ferramenta de desenvolvimento territorial endógeno, a partir do aproveitamento de sua singular paisagem para as práticas do turismo desenvolvido sobre bases sustentáveis.

\section{Referências Bibliográficas}

AULER, A.; STÁVALLE, Y. Novas cavernas cadastradas no Rio Grande do Sul. Conexão Subterrânea. Boletim Rede Speleobrasil, no 22, jun., 2005. Disponível em: <http:// www.redespeleo.org/asmin/arquivos/86111719 conexa022.pdf>. Acesso em: 5 dez. de 2011.

AZEVEDO, U. R. de. Patrimônio geológico e geoconservação no Quadrilátero Ferrífero, Minas Gerais: potencial para a criação de um geoparque da UNESCO. Tese de doutorado, Programa de Pós-graduação em Geologia da Universidade Federal de Minas Gerais, UFMG, Belo Horizonte, 2007. Disponível em: <http://www.bibliotecadigital.ufmg.br/ dspace/handle/1843/MPBB-76LHEJ>. Acesso em: 26 nov. 2011.

BOGGIANI, P. C. A aplicação do conceito de Geoparque da UNESCO no Brasil e a relação com o SNUC - Sistema Nacional de Unidades de Conservação. Revista Patrimônio Geológico e Cultura. v.1, n.1, junho de 2010. Disponível em: <http:// www.geoturismobrasil.com/001\%20-\%20REVISTA.html>. Acesso em: 26 nov. 2011. 
BORBA, A. W. Evolução geológica da "Bacia do Camaquã" (Neoproterozóico e Paleozóico Inferior do Escudo sul-rio-grandense, RS, Brasil): uma visão com base na integração de ferramentas de estratigrafia, petrografia e geologia isotópica. 2006. 121f. Tese de Doutorado. Universidade Federal do Rio Grande do sul - Departamento de Geociências. Porto Alegre, 2006.

BRILHA, J. Patrimônio Geológico e Geoconservação: A Conservação da Natureza na sua Vertente Geológica. Braga: Palimage Editores, 2005.

CARVALHO, C. N.; RODRIGUES, J.; JACINTO, A. (Eds.) Geoturismo \& Desenvolvimento Local. Rio Maior (Portugal): Printmor, 2009.

CPRM. Serviço Geológico do Brasil. Projeto Geoparques. Disponível em: <http:// www.cprm.gov.br/>. Acesso em: 27 nov. 2011.

DEGRANDI, S. M. Ecoturismo e Interpretação da Paisagem no Alto Camaquã/RS: uma alternativa para o (des)envolvimento local. Dissertação de Mestrado. Santa Maria: Programa de Pós-graduação em Geografia e Geociências (PPGGeo), Universidade Federal de Santa Maria, UFSM, 2011.

DOWLING, R.; NEWSOME, D. Geotourism: Sustainability, impacts and management. Elsevier, 2006.

FACCINI, U. F. et al. Metodologia e processo de integração de dados em um estudo multidisciplinar. In: RONCHI, L. H.; LOBATO, A. O. C. (Org.) Minas do Camaquã: um estudo multidisciplinar. São Leopoldo: UNISSINOS, (p. 263-272), 2000.

HOSE, T.A. The significance of aesthetic landscape appreciation to modern geotourism provision. In : NEWSOME, D.; DOWLING, R.K. (Eds.) The Tourism of Geology and Landscape. Oxford: Goodfellow Publishers Ltd, (p.13-26), 2010.

IBGE. Folha SH. 22 Porto Alegre e parte das folhas SH. 21 e SI. 22 Lagoa Mirim: geologia, geomorfologia, pedologia, vegetação, uso potencial da terra. Rio de Janeiro: IBGE, 1986. (Levantamento de recursos naturais, v.33).

MANSUR, K. L. Ordenamento Territorial e Geoconservação: análise das normas legais aplicáveis no Brasil e um caso de estudo no Rio de Janeiro. São Paulo: UNESP, Geociências, v.29, n.2, pp.237-249, 2010. Disponível em: <http://drifte.rc.unesp.br/ revistageociencias/29 2/Art\%207 Mansur.pdf>. Acesso em: 26 nov. 2011.

MARQUES, A. A. B. et al. Lista de Referência da Fauna Ameaçada de Extinção no Rio Grande do Sul. Decreto no 41.672, junho de 2002. Porto Alegre: FZB/MCT-PUCRS/ PANGEA, 2002. (Publicações Avulsas FZB, 11).

MINISTÉRIO DO MEIO AMBIENTE. Avaliação e ações prioritárias para a conservação da biodiversidade da Mata Atlântica e Campos Sulinos/por: Conservation International do Brasil, Fundação SOS Mata Atlântica, Fundação Biodiversitas, Instituto de Pesquisas Ecológicas, Secretaria do Meio Ambiente do Estado de São Paulo, SEMAD/Instituto Estadual de Florestas-MG. Brasília: MMA/SBF, 2000. Disponível em: <http://www.rbma.org.br/ anuario/mata 04 areas prioritarias.asp >. Acesso em: 4 dez. 2011. 
NASCIMENTO, M. A. L. RUCHKYS, U. A. MANTESSO-NETO, V. Geoturismo: um novo segmento do turismo no Brasil. Global Tourism, v. 3, n.2, Novembro de 2007. Disponível em: <www.periodicosdeturismo.com.br>. Acesso em: 26 nov. 2011.

PAIM, P. S. G; LOPES, R. C. Geologia da Região das Minas do Camaquã. In: RONCHI, L. H.; LOBATO, A. O. C. (Org.) Minas do Camaquã: um estudo multidisciplinar. São Leopoldo: UNISSINOS, (pp 111- 132), 2000.

PAIM, P. S. G. Minas do Camaquã (RS): marco da história da mineração de cobre no Brasil. Sítios Publicados, v. I, SIGEP, 2009. Disponível em: <http://www.ig.unb.br/sigep/ sitio064/sitio064.pdf>. Acesso em: 8 dez. 2011. Acesso em: 8 dez. 2011.

PAIM, P. S. G; FALLGATTER, C; SILVEIRA, A. S. da. Guaritas do Camaquã (RS): Exuberante cenário com formações geológicas de grande interesse didático e turístico. SIGEP- Comissão Brasileira de Sítios Geológicos e Paleobiológicos/sítios Publicados, 2010. Disponível em: <http://sigep.cprm.gov.br/sitios.htm\#Vol1>. Acesso em: 8 dez. 2011.

PEREIRA, R. G. F. A. de. Geoconservação e Desenvolvimento Sustentável na Chapada Diamantina (Bahia - Brasil) - Tese de Doutoramento. Universidade do Minho (Portugal), 2010. Disponível em: <http://www.geoturismobrasil.com/artigos/TESE-Ricardo\% 20Fraga.pdf>. Acesso em: 26 nov. 2011.

PEREIRA, R. F.; BRILHA, J.; MARTINEZ, J. E. Proposta de enquadramento da geoconservação na legislação ambiental brasileira. Memórias e Notícias, n. 3. Braga: Universidade do Minho, (pp. 491-494), 2008.

RONCHI, L. H.; LOBATO, A. O. C. (Org.) Minas do Camaquã: um estudo multidisciplinar. São Leopoldo: UNISSINOS, 2000.

SCHOBBENHAUS FILHO. C. Relatório de Viagem a Portugal: Geoparque Arouca e Naturtejo. Ministério de Minas e Energia, Secretaria de Geologia, Mineração e Transformação Mineral, Serviço Geológico do Brasil - CPRM, 2010. Disponível em: <http:// www.cprm.gov.br/publique/media/geoparque arouca naturtejo portugal.pdf $>$. Acesso em: 27 nov. 2011.

SCHOBBENHAUS FILHO, C.; SILVA, C. R. da. O papel indutor do Serviço Geológico do Brasil na criação de geoparques. Anais... I Fórum do Patrimônio Cultural. Painel: Paisagem Cultural e Patrimônio Natural: Conceitos e Aplicabilidade, Ouro Preto, 2009. Disponível em: <http://sigep.cprm.gov.br/destaques/Schobbenhaus Silva 2010.pdf>. Acesso em: 27 dez. 2011.

SEPLAG. Secretaria de Planejamento e Gestão do Rio Grande do Sul. Projeto Conservação da Biodiversidade como fator de contribuição ao desenvolvimento do Estado do Rio Grande do Sul. 2008. Disponível em: <http://www.seplag.rs.gov.br>. Acesso em: 3 dez. 2011.

SEPLAG. Secretaria de Planejamento e Gestão do Rio Grande do Sul. Projeto Conservação da Biodiversidade como Fator de Contribuição ao Desenvolvimento do Estado do Rio Grande do Sul: Diagnóstico das Áreas Prioritárias. Estado do Rio Grande do Sul, Secretaria de Planejamento e Gestão, 2005b. Disponível em: <http://www.seplag.rs.gov.br>. Acesso em: 3 dez. 2011. 
SHARPLES, C. Concepts and principles of geoconservation. 2002. Disponível em:<http://www.dpiw.tas.gov.au/inter.nsf/Attachments/SJON57W3YM/\$FILE/ geoconservation.pdf>. Acesso em: 26 nov. 2011.

SILVA, C. R. da. Geodiversidade do Brasil: conhecer o passado, para entender o presente e prever o futuro. Rio de Janeiro: CPRM, 2008.

SLOMKA, T.; MAYER, W. Geotourism and geotourist education in Poland. In: NEWSOME, D.; DOWLING, R.K. (Eds.) The Tourism of Geology and Landscape. Oxford: Goodfellow Publishers Ltd, (p.142-157), 2010.

VIEIRA, E. F. Rio Grande do Sul: geografia física e vegetação. Porto Alegre: Sagra, 1984.

\section{Notas}

${ }^{1}$ Trabalho apresentado no VIII CONECOTUR e IV ECOUC, em novembro de 2011.

${ }^{2} U m$ Geossítio ou sítio geológico, segundo Brilha (2005), pode ser definido como ocorrência de um ou mais elementos da geodiversidade (aflorantes quer em resultado da ação de processos naturais, quer em resultado da intervenção humana), bem delimitado geograficamente e que apresente valor singular do ponto de vista científico, pedagógico, cultural, turístico ou outro.

Simone Marafiga Degrandi: Universidade Federal de Santa Maria, Santa Maria, RS, Brasil.

Email: simone5z@yahoo.com.br

Link para currículo Lattes: http://lattes.cnpq.br/8716980240343740

Adriano Severo Figueiró: Universidade Federal de Santa Maria, Santa Maria, RS, Brasil.

Email: adri.geo.ufsm@gmail.com

Link para currículo Lattes: http://lattes.cnpq.br/0669013150421592

Data de submissão: 11 de janeiro de 2012

Data de recebimento de correções: 30 de Abril de 2012

Data do aceite: 11 de Abril de 2012

Avaliado anonimamente 